\title{
Nación, mito e historia: la Guerra Hispano-Cubano-Norteamericana en el cine
}

Santiago Juan-Navarro

Florida International University (Estados Unidos) 



\title{
Nación, mito e historia: la Guerra Hispano-Cubano- Norteamericana en el cine
}

\section{Nation, Myth and History: the Spanish-Cuban-American War in the Cinema}

\author{
Santiago Juan-Navarro \\ Florida International University (Estados Unidos) \\ navarros@fiu.edu
}

Fecha de recepción: 5 de marzo de 2018

Fecha de aceptación: 20 de mayo de 2019

\section{Resumen}

El presente ensayo estudia desde una perspectiva comparada las representaciones de la Guerra hispano-cubano-norteamericana en el cine de ficción y no ficción y su trascendencia en la construcción de imaginarios nacionales basados en relaciones de dominación y resistencia. Si el cine norteamericano ha representado la contienda como la confirmación de su Destino Manifiesto y su proyección internacional, en el caso español ha dado lugar a visiones que oscilan entre las nostalgias imperiales del cine franquista y el revisionismo histórico de finales del siglo XX. El cine cubano, por su parte, ha visto en el enfrentamiento el origen de un largo ciclo de insurrecciones que habrían de culminar con el triunfo de la revolución de 1959. En los tres casos, se recurre a una visión maniquea, propagandística y mesiánica de la historia; una visión que responde al ámbito del mito y la escatología, más que al de la historia propiamente dicha.

Palabras clave: Nación; Mito; Guerra Hispano-Cubano-Norteamericana (18951898); Guerra de Cuba (1895-1898); Propaganda; Cine bélico

\begin{abstract}
Using a comparative perspective, this article explores cinematic (fictional and non-fictional) representations of the Spanish-Cuban-American War, as well as their importance in the construction of national imageries based on relations of dominance and resistance. While US cinema has portrayed the conflict as the validation of the nation's Manifest Destiny and the beginning of its international projection, in the case of the Spain it has resulted in opposite views that go from the Francoist period's imperial nostalgia to the revisionist views of the late 1990s. As for Cuban cinema, it has sought in this confrontation the origin of a long series of struggles for independence that culminated with the triumph of the Revolution in 1959. In all three cases, films resort to a Manichean, propagandistic, and Messianic view of history; a view that responds to the realm of myth and eschatology, rather than to the one of history itself.
\end{abstract}

Keywords: Nation; Myth; Spanish-Cuban-American War (1895-1898); SpanishAmerican War (1895-1898); Propaganda; War films 


\section{INTRODUCGIÓN}

La Guerra de 1898 tuvo una importancia capital para las tres naciones beligerantes: Estados Unidos, España y Cuba. Todas ellas coincidieron en valorar el conflicto como un punto de inflexión en sus respectivas historias políticas y culturales. A diferencia de muchos acontecimientos que solo adquieren significado con el paso del tiempo, el 98 fue un fenómeno cuya magnitud pudo vislumbrarse a medida que se producían los hechos. Para los historiadores norteamericanos, la fecha conmemora el instante en el que Estados Unidos se proyecta como superpotencia en la esfera internacional. Para los españoles supuso el "desastre", el fin de un imperio colonial ultramarino que había perdurado (y languidecido) a lo largo de cinco siglos. Para Cuba representaba la transformación de colonia en nación, pero sujeta a una ambigua condición neocolonial bajo la mirada vigilante de la nueva potencia hegemónica. No es pues de extrañar que esta guerra haya dado lugar a una ingente bibliografía. Los estudios sobre el tema llegaron a alcanzar un volumen masivo con los actos conmemorativos del centenario que tuvieron lugar a fines del siglo pasado. Sin embargo, hay un aspecto fundamental del conflicto que solo ha sido tratado de forma dispersa: la representación cinematográfica de la guerra y su contribución a la configuración de un imaginario nacional que en cada uno de los casos ha buscado legitimar su propio discurso hegemónico mediante intensas campañas de propaganda institucional. Esta carencia es particularmente llamativa dada la relación simbiótica que la guerra hispano-cubano-norteamericana tuvo con los orígenes del cine como medio de comunicación de masas. A la insuficiencia de estudios sobre esta cuestión habría que añadir la escasez de perspectivas comparadas que iluminen un suceso que solo puede entenderse más allá de los límites geográficos y discursivos de cada uno de los países implicados. ${ }^{1}$ Adoptando una perspectiva tripartita, examinaré a continuación la representación de la guerra en las cinematografías de EE.UU., España y Cuba.

\section{DESARROLLO}

2.1. "A splendid little war": el 98 en el sine norteamericano

It has been a splendid little war, begun with the highest motives, carried on with magnificent intelligence and spirit, favored by that Fortune which loves the brave.

John Hay

1 La única visión global del tema la ofrece Alejandro Pizarroso Quintero (1998) en un artículo muy general (más descriptivo que analítico) y que pasa por alto el componente mítico y legitimador del conflicto. 
Revista de Humanidades, 37 (2019). p. 179-208. ISSN 1130-5029

A fines del siglo XIX los Estados Unidos habían concluido su expansión hacia el Oeste y todavía estaban vivos los ecos del llamado Destino Manifiesto. En 1893 Frederick Jackson Turner, un joven profesor de historia presentaba "The Significance of the Frontier in American History" en el marco de las celebraciones del cuarto centenario de la llegada de Colón a tierras americanas. En este ensayo, que habría de convertirse pronto en uno de los documentos más influyentes de la historiografía norteamericana, Turner establecía una relación directa entre el carácter estadounidense y el desarrollo político de la frontera como ideal e ideología: "The existence of an area of free land, its continuous recession, and the advance of American settlement westward explain American development" (1921, p. 1). Toda la historia nacional remitía a una constante expansión de esa frontera que, una vez, alcanzados los límites continentales, empezó a contemplar la posibilidad de extenderse a territorios ultramarinos. A finales del XIX se daban las condiciones ideales para acometer tal empresa. Las potencias coloniales europeas tenían cada vez menos peso en el hemisferio occidental y los Estados Unidos, que ya en 1823 a través de la Doctrina Monroe habían hecho popular la consigna de "América para los americanos", dejaron claro que cualquier intervención europea en América sería vista como un acto de agresión y justificaría una intervención militar. Para comienzos de la década de 1890 los estadounidenses, que ya consideraban el Caribe como su propio mar, empezaron también a ver a su país como una potencia naval con aspiraciones sobre el Atlántico y el Pacífico, tal y como se deprende del popular libro de Alfred Thayer Mahan The Influence of Sea Power upon History (1890). La misión de la marina norteamericana había pasado de limitarse a proteger sus fronteras a defender (e imponer) sus ideas, intereses y poder en todo el mundo. Las tesis de Mahan y de Turner se unieron así a las de Monroe y el Destino Manifiesto, para legitimar una guerra con España que marcaría el comienzo de la expansión global de los Estados Unidos, dentro de una dinámica que se prolonga hasta el presente y valiéndose de una retórica que aún hoy día sigue combinando de forma anacrónica, pero eficaz, el idealismo anticolonial de sus orígenes con ambiciones claramente imperiales. ${ }^{2}$ Ahora bien, la trascendencia del 98 supera los límites de la esfera política y militar. En gran medida fue el mundo de la cultura (y especialmente el de la cultura popular y de masas) el responsable de una forma "imperial" de percibir la realidad por parte del pueblo norteamericano.

2 Las interpretaciones sobre el imperialismo son inseparables de los debates sobre su existencia. La noción de un imperio estadounidense pudo parecer en sus orígenes una contradicción, ya que la percepción popular de la política internacional siempre había sido la de una nación democrática inherentemente antiimperialista (desde su fundación a raíz de la Revolución Americana contra el imperio británico hasta la Guerra Fría contra el "imperio del mal" encarnado en la URSS). Desde esta perspectiva, las intervenciones en el extranjero (ya fueran estas militares, económicas, políticas o culturales) habían sido (y siguen siendo) percibidas por muchos como actos de liberación, esfuerzos por defender a los pueblos oprimidos de la agresión de otros imperialismos. 
Es ya un lugar común conectar la guerra hispano-cubano-norteamericana con el auge de los medios de comunicación de masas y especialmente con la prensa amarilla. El conflicto coincide con el del periodismo bélico en todo el mundo y el desarrollo de las comunicaciones. Como han señalado muchos historiadores, la guerra del 98, no hubiera tenido lugar sin el impulso resuelto de la prensa nacional (Pizarroso Quintero, 1998, p. 145). La simpatía del pueblo estadounidense por la causa cubana hubiera sido difícilmente comprensible sin unos medios que la magnificaron hasta extremos hiperbólicos. Es de todos conocidos el papel decisivo que tuvieron en este sentido Joseph Pulitzer (New York World) y William Randolph Hearst (New York Journal). Interpretando la preocupación popular en torno a la lucha del pueblo cubano como un producto del idealismo norteamericano mezclado con un deseo de expansión económica y militar, Pulitzer y Hearst alimentaron el apetito de los lectores por historias truculentas sobre la crueldad de los españoles. Ambos eran, además, declarados entusiastas del Destino Manifiesto y pronto vieron en la represión llevada a cabo en Cuba por el general Valeriano Weyler (popularmente conocido en la prensa norteamericana como "the Butcher") la excusa perfecta para conmover al lector y reclamara la intervención militar en la isla.

Menos conocida, sin embargo, es la conexión de la guerra con el desarrollo de la incipiente industria cinematográfica. Si bien es cierto que el cine estuvo al servicio de la guerra como arma de propaganda a lo largo de todo el siglo XX, durante 1898 tuvo un papel único en la diseminación masiva de imágenes propagandísticas que llegaron a modelar la opinión pública. Debido al carácter inaugural de este acontecimiento, el cine contribuyó a fijar visualmente en el imaginario nacional la percepción que los norteamericanos tenían de sí mismos y su relación con el mundo. Pero no solo fue importante en su dimensión visual, también lo fue en sus posibilidades narrativas. Si toda nación responde a los relatos de su comunidad imaginada, el cine, con su capacidad para contar historias de gran impacto emocional que eran consumidas de forma colectiva, se convirtió en el vehículo ideal para trasmitir narrativas nacionales (Shohat y Stam, 1993, p. 101), y en este caso, las de una nación que comenzaba a mostrar además ambiciones de carácter imperial.

Hacía muy poco que la imagen comercial en movimiento había echado a andar en EE.UU. cuando se declaró la guerra contra España en abril de 1898. Los camarógrafos de las compañías de Edison y Biograph se unieron a los periodistas de Hearst en el yate que fletó para cubrir la campaña. Durante más de un año las masas consumieron ávidamente en los teatros de las ciudades y en exhibiciones itinerantes las películas relacionadas con la guerra. Estos breves cortometrajes de menos de un minuto de duración mostraban motivos tales como los restos del Maine y el entierro de sus víctimas, tropas marchando y desembarcando, los Rough Riders cabalgando, soldados descansando en los campamentos o los triunfales desfiles de la victoria en honor del Admirante Dewy y de las tropas que regresaban del campo de batalla. Además, los filmes presentaban dramatizaciones de las batallas en Cuba y Filipinas 
Revista de Humanidades, 37 (2019). p. 179-208. ISSN 1130-5029

que, por las limitaciones técnicas de la época, habían sido rodadas en New Jersey y conflictos navales simulados en bañeras con maquetas de barcos.

El cine ofreció la oportunidad no solo de la contemplación pasiva de lo que Charles Musser llamó "diarios visuales", sino también para la expresión pública (y a menudo exaltada) del sentimiento nacionalista: los espectadores de los teatros jaleaban con vítores y aplausos la victoria de Dewey, abucheaban la presencia de la familia real o los militares españoles, entonaban a coro canciones patrióticas y saludaban la archi-representada imagen de la bandera estadounidense izándose sobre el Castillo del Morro en La Habana. Cuando la guerra estaba en pleno apogeo estos filmes llegaron a ser tan populares que se exhibían en sesiones continuas en los teatros, donde las multitudes compartían un sentimiento de histeria patriótica colectiva. Los proyectores como el Kinescope de Edison, que empezaban a ser popularmente conocidos como el Warograh or el Warscope, ofrecían una experiencia de una inmediatez sin precedentes; experiencia en la que el deseo de ver el propio espectáculo de la guerra superaba cualquier interés en el contexto político o en el conflicto bélico propiamente dichos.

Estos primeros filmes fueron inicialmente interpretados como proto-noticieros o como manifestaciones del llamado "cine de atracciones". Este último concepto, que el crítico Thomas Gunning propuso a finales de los ochenta, alude a la capacidad que las imágenes cinematográficas tenían en sus orígenes (especialmente hasta 1907) para despertar el interés del espectador sin necesidad de acomodarse a una clara estructura narrativa (Gunning, 1986, pp. 58-70). A menudo, el atractivo de estos cortometrajes de guerra había que buscarlo no tanto en su exhibición de lugares y pueblos exóticos (generalmente ausentes) o en las escenas de combate (imposibles de filmar por las limitaciones técnicas del medio), como en el espectáculo de la movilidad misma, una cualidad inherente al carácter nacional (Kaplan, 1999, p. 1069; Riesman, 2001, pp. 14, 40). El movimiento domina la representación de las tropas norteamericanas, representadas siempre de forma dinámica. Por el contrario, las pocas imágenes de cubanos, españoles y filipinos tienden a ser estáticas (aparecen sentados, esperando en cola las raciones, o de pie frente a un pelotón de fusilamiento, poco antes de morir). En las reconstrucciones de los combates, los soldados norteamericanos, por el contrario, enfrentan abiertamente la cámara, o esta se sitúa detrás de los soldados que disparan directamente contra el fuego enemigo, de modo que la relación visual en los teatros donde se proyectaban estas películas no se daba entre las tropas estadounidenses y sus enemigos, sino entre los soldados norteamericanos y el público de su propio país que contemplaba enardecido tales imágenes. Los paisajes de Cuba y Filipinas (o su simulación) ocupaba un lugar secundario, mero decorado de una acción que celebra la movilidad del espíritu estadounidense en geografías exóticas.

Pero los filmes sobre la guerra hispano-cubano-norteamericana pronto fueron más allá del cine atracciones. Como mencioné anteriormente, la exhibición de estos productos desempeñó un papel fundamental en el desarrollo de la narrativa 
cinematográfica. Antes de la guerra, las películas, de apenas un minuto de duración, eran exhibidas como espectáculo de variedades dentro de un formato que incluía temas dispares entrelazados con otras formas de entretenimiento, sin una clara unidad temática o continuidad narrativa. En el caso de los filmes de la guerra del 98, el fermento patriótico generado en torno a la guerra con España y la espléndida acogida que tuvieron en el público de las grandes ciudades, llevó a los exhibidores a organizar por primera vez tales segmentos conforme a un tema unificador y en torno a una narrativa cronológica que contaba la historia y el desarrollo de la guerra. Así, se incluía, por ejemplo, la recreación de la destrucción del Maine, el funeral de sus víctimas, el embarque de tropas rumbo a los campamentos de Cuba, estampas de la vida de los soldados y los desfiles de bienvenida que se ofrecieron a las tropas a su regreso. Para Stephen Bottomore tales sesiones dieron lugar a los primeros "largometrajes" (2007, p. 33) de la historia del cine. Esta coherencia temática y cronológica, contribuyó, asimismo, al desarrollo del cine narrativo, que terminaría por convertirse en el modo dominante de expresión cinematográfica durante el siglo XX (Musser, 1990, p. 261).

La relación entre los orígenes del cine y la guerra del 98 fue, como he venido apuntando, simbiótica. Si el cine contribuyó a dar una dimensión "espectacular" sin precedentes al conflicto, este ofreció un motivo muy atractivo para el espectador norteamericano. Así, los filmes sobre el 98 sirvieron para consolidar una industria que, tras su despegue inicial, atravesaba una crisis y se encontraba envuelta en una lucha intestina entre patentes y compañías. ${ }^{3}$ A medida que las disputas dentro de la industria cinematográfica alcanzaban nuevas cotas de intensidad, los EE.UU. se vieron implicados en una guerra real. El 15 de febrero de 1898, mientras Edison se enzarzaba en un pleito contra Klaw \& Erlanger, el USS Maine estallaba en el puerto de La Habana. La crisis cubana y la guerra consiguiente fueron un balón de oxígeno para la industria cinematográfica. Aunque Hearst, Pulitzer y otros editores alimentaban la indignación norteamericana ante lo que consideraron el hundimiento provocado del Maine, la lectura de la retórica inflamada de sus diarios seguía siendo un acto privado. Fueron los teatros donde se mostraban las películas los que permitieron dar rienda suelta a la manifestación pública, colectiva y contagiosa de las emociones de los espectadores. Si la simple exhibición de la bandera o la interpretación del himno nacional provocaban demostraciones desmedidas de júbilo, podemos imaginarnos el efecto que tendría la proyección de imágenes del Maine en

3 Robert C. Allen indica cómo, durante la Guerra Hispano-Americana, el Biograph se convirtió en una atracción estelar del vodevil a medida que el cine norteamericano fue adquiriendo el nuevo papel de "periódico visual" (1977, p. 139). Los filmes bélicos se sucedieron a lo largo del verano de 1898, convirtiendo la guerra con España en el acontecimiento más determinante para el despegue del cine como industria en sus primeros años. En su historia de la exhibición cinematográfica en EE.UU., Douglas Gomery también le asigna a los cortometrajes de la guerra hispano-cubano-americana un papel de primer orden en la era anterior al Nickelodeon (1992, p. 16). Lauren Rabinovitz llega a sugerir que el boom del mercado cinematográfico podría haberse venido abajo si no hubiera sido por el estallido de la guerra con España en 1898 (1998, p. 107). 
Revista de Humanidades, 37 (2019). p. 179-208. ISSN 1130-5029

todo su esplendor. Y cuando no existían tales imágenes, éstas eran inmediatamente manufacturadas mediante dramatizaciones y simulacros.

Como las tan deseadas y anticipadas imágenes de los combates "reales" nunca llegaron a materializarse, lo que se exhibía en los teatros era en su mayor parte una realidad fabricada (Sklar, 1975, p. 22). Las nuevas tecnologías bélicas, que permitían tácticas de enfrentamiento a larga distancia, imposibilitaban su filmación con cámaras, que por aquel entonces eran difíciles de transportar y carecían de teleobjetivos. Aunque en los periódicos de la época pueden encontrarse anuncios que prometían "action galore", en la práctica, como indica Bottomore, los camarógrafos no podían acercarse al campo de batalla, viéndose limitados a plasmar simplemente "el lado humano de la guerra": escenas en los hospitales, el movimiento de tropas y la vida cotidiana en los campamentos $(2007$, p. 30$){ }^{4}$

Edison pronto empezó a filmar las actualidades de los Rough Riders de Roosevelt, que aparecían desembarcando o en formación y más tarde dramatizaría las escaramuzas del pintoresco grupo en secuencias rodadas en West Orange, New Jersey. Tal fue el caso de U.S. Infantry Supported by Rough Riders at El Caney, Skirmish of Rough Riders, Roosevelt's Rough Riders Embarking for Santiago. El 2 de julio de 1898 el New York Clipper anunciaba una supuesta película de la guerra (Bobardment of Matanzas), filmada gracias a una nueva lente telescópica que permitía a los espectadores contemplar imágenes de la batalla que tuvo lugar en la Bahía de Cuba. Lo prometido por el anuncio, por supuesto, era falso. ${ }^{5}$ El filme era simplemente una reconstrucción del combate rodado en Waukegan, Illinois y producido por la compañía de Edward H. Amet poco después del comienzo de las hostilidades. Amet, un ingeniero eléctrico, realizó varias reconstrucciones de la Guerra durante aquellos años: Flagship New York Under Way, Spanish Fleet Destroyed, Dynamite Cruiser Vesuvius y Firing Broadside at Cabanas. También rodó tableaux alegóricos, como el famoso Freedom of Cuba (1898), que revela las actitudes norteamericanas ante el imperialismo y la guerra hispano-norteamericana. La puesta en escena puede ser interpretada como el nacimiento de un nuevo orden panamericano en el que el Tío Sam acoge bajo su protección a una Cuba infantil, incapaz del autogobierno, que deja caer la bandera cubana para abrazar los ideales estadounidenses (fig. 1). Este motivo se convirtió en un tropo de la retórica imperialista durante la guerra, ejemplificado en el poema de Rudyard Kipling "White man's burden". El tema es un mandato

4 Como recordaba en sus memorias el corresponsal Billy Bitzer: "Visiting Cuba under Spanish rule was highly dangerous [...] My camera was bulky enough, but [...] it was [also] driven by a motor operated by over two thousand pounds of storage batteries [...]" (1973, p. 34). Para empeorar aún más las cosas, el desembarco en Cuba fue tan caótico, que muchos de los caballos tuvieron que ser dejados en Tampa y Bitzer no pudo viajar con las tropas, de modo que tuvo que pasar la mayor parte del tiempo en el yate de Hearst (1973, pp. 36-46).

5 Las películas que reconstruyen y/o dramatizan momentos de la guerra de Cuba, se adscriben a la categoría de fake dentro del cine de los orígenes. Sobre esta categoría, véase Kessler y Lenk (2018, pp. 228-236). 
retórico al hombre blanco para que colonice a las demás razas para beneficio de estas, siendo su "carga" tanto la tarea encomendada como los propios pueblos que estaba moralmente obligado a colonizar.

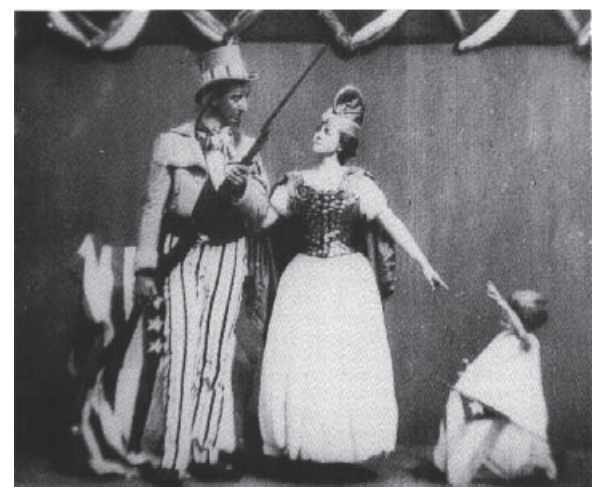

Figura 1: Alegoría de Edward Amet, Freedom of Cuba (1898). Library of Congress. CSJ-N

Durante las primeras décadas del siglo XX el cine fue perdiendo su interés en la recreación cinematográfica del 98. Los filmes sobre el periodo se centraron casi exclusivamente en la figura de Theodore Roosevelt y sus Rough Riders, que pronto se convirtieron además en uno de los motivos favoritos de la cultura popular y un auténtico mito fundacional del expansionismo norteamericano (Gagliasso, 2000, p. 308). A lo largo de décadas el público quedó cautivado por su esa curiosa (y poco ortodoxa) banda de ciudadanos-soldados que lucharon en favor de una causa popular. Más de 20.000 fueron reclutados por todo el país. Conocido también como "the Cowboy regiment" ya que la mayoría fueron reclutados en los Estados del Oeste (Arizona, New Mexico, Oklahoma y el territorio indio), la Primera Caballería de voluntarios incluía, además de vaqueros, indígenas, bandidos, representantes de la ley, congresistas, deportistas universitarios, Ivy Leaguers, periodistas, antiguos soldados del ejército regular, unos setenta extranjeros y hasta un pastor protestante. Theodore Roosevelt y sus Rough Riders aparecieron frecuentemente representados en espectáculos como los creados por Buffalo Bill, a quien se le atribuye el mérito de haber ayudado a mantener viva su leyenda cubriéndola de otros mitos asociados al Viejo Oeste que atraían al público de las grandes ciudades.

Especialmente destacada fue la gran superproducción que Paramount Studies encargó a Victor Flemming: The Rough Riders (1925). Aunque no se conserva ninguna copia completa, es relativamente fácil reconstruir la versión final consultando los diferentes guiones disponibles, así como el abundante material gráfico archivado en la colección de la AMPAS (Academy of Motion Picture Arts and Sciences) y que incluye fotografías del rodaje, fotogramas de la película, artículos y reseñas de revistas. El filme tenía unas claras ambiciones épicas, como evidenciaban su presupuesto de un millón y medio de dólares (desorbitado para una época en la que el coste medio de un 
Revista de Humanidades, 37 (2019). p. 179-208. ISSN 1130-5029

largometraje no superaba los \$200.000), el gran despliegue de medios y la atracción que generó. En su pretendida fidelidad a los acontecimientos históricos (dentro, por supuesto, de los estrechos límites propios del cine histórico del Hollywood), así como en su intento de evitar los estereotipos raciales, la película de Fleming fue también bastante inusual para la época. La película recibió buenas reseñas por parte de los críticos, pero fue un fracaso en taquilla. Ni siquiera consiguió acercarse de lejos a recuperar el dinero invertido por Paramount. Pero si hemos de juzgarla por los breves fragmentos que han llegado a nosotros, los reportajes fotográficos y el guión, The Rough Riders debió haber sido una espectacular recreación histórica.

Varias décadas después, en vísperas del centenario del 98 John Milius dirigió una recreación homónima, muy similar y de ambiciones igualmente épicas: Rough Riders (1997). Cabe recordar que los actos conmemorativos del 98 en los Estados Unidos estuvieron marcados por tendencias disímiles. Si bien algunos mantuvieron la visión providencialista y mesiánica que dominó tanto la historiografía como la política exterior norteamericana durante décadas, otros decidieron reformular las causas y consecuencias del conflicto a la luz del expansionismo norteamericano. La obra de Milius (fig. 3) se adscribe claramente al primer grupo. Realizada para la televisión en forma de miniserie y por encargo del canal de cable norteamericano TNT, Rough Riders es una de las más detalladas, ambiciosas representaciones de Roosevelt y el Primer Regimiento de Caballería. También es, desde luego, una de las más reaccionarias. La imagen que comunica la serie, si bien se acomoda más al formato del Western que al del cine histórico propiamente dicho, resume bastante bien la gran narrativa sobre el conflicto que durante cien años había transmitido la cultura popular norteamericana. Con un coste de 20 millones de dólares fue la producción dramática más costosa acometida por un canal de TV por cable. Más de 500 extras participaron en la película, que se filmó en más de media docena de locaciones por todo el Estado de Texas. Se trata de una exaltación acrítica que mistifica la figura del político norteamericano dentro de la estética de los Westerns clásicos; una idealización que defiende sin reparos un patrioterismo caricaturesco y una visión nostálgica de la historia nacional. Como declaró el actor Sam Elliot, que encarnaba al capitán Buckey O'Neill en la miniserie: "This film takes us back when everyone was proud to be an American and go off to war" (Gagliasso, 2000, p. 325).

Muchos de los personajes históricos asociados a los Rough Riders fueron reecreados en el filme: el general Joseph Wheeler, el coronel Leonard Wood, los capitanes Allan Capron y Woodbury Wheeler, el artista Frederic Remington y el escritor Stephen Crane, entre otros. Para asegurarse fidelidad al registro histórico, Milus contó con la participación de varios asesores históricos y militares (todos ellos próximos a su propia ideología política). Pero, en realidad, la base historiográfica del filme en una adaptación bastante fiel del libro de memorias sobre la campaña que escribió el propio Roosevelt (The Rough Riders, 1899). Millius y su coguionista, Hugh Wilson, tomaron el relato de Roosevelt literalmente y convirtieron la película en una celebración entusiasta de los valores de la masculinidad, el espíritu de equipo, 
el militarismo y la idea del Destino Manifiesto, añadiendo, como ya hubiera hecho anteriormente la película de Fleming una subtrama heredada de la novela de Stephen Crane, The Red Badge of Courage (1895).
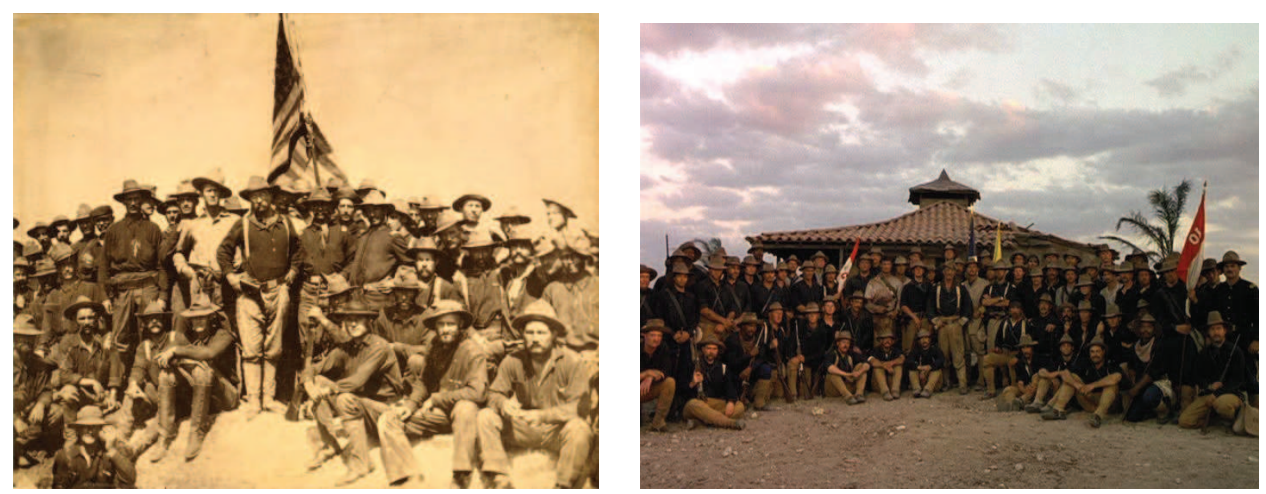

Figura 2: Roosevelt con el Primer Regimiento de Caballería (1898) en la cima de la colina de San Juan [izquierda]. Library of Congress. A la derecha, Fig. 3: reconstrucción de John Milius para la miniserie de TV Rough Riders (1998). Turner Network Television. CSJ-N

El año del centenario fue testigo también de una larga serie de documentales que exploraban la guerra desde una perspectiva revisionista, aunque no especialmente crítica. En 1998, el History Channel produjo un programa de dos horas (The Spanish American-War: Birth of a Super Power) para conmemorar el centenario del conflicto. El documental, dirigido por Lou Reda, representa la guerra como la responsable de la transformación de los EE.UU. de "a political pygmy to a domination world power". Empezando con el hundimiento del Maine, al que se califica como el más controvertido comienzo de un conflicto bélico norteamericano, y la cruel política de contrainsurgencia llevado por el General Weyler contra los rebeldes cubanos, Birth of a Super Power examina el conflicto en Cuba y el Pacífico en relación con el trasfondo de lo que califica como "a new American restlessness". Para ello se vale de material de archivo, dramatizaciones y comentarios de varios historiadores. El filme explora el dilema subyacente en las motivaciones del pueblo norteamericano, que oscilaban entre el idealismo (la necesidad de poner fin a los abusos del pueblo cubano) y los intereses geopolíticos (el impulso de extender sus propias fronteras más allá de los Estados de la Unión). De forma similar la serie de dos episodios Destiny of Empires: The Spanish American War of 1898 (1998) se centra en las causas, los protagonistas, y las consecuencias políticas de la guerra. "Remember The Maine": The Roots of the Spanish-American War (1998) se vale de material de archivo, fragmentos de la prensa y documentos históricos para establecer las raíces del conflicto, mientras que The Spanish-American War: A Conflict in Progress (1998) reexamina de forma concisa algunos momentos destacados, desde el papel de los Rough Riders de Roosevelt hasta el Tratado de París. 
Revista de Humanidades, 37 (2019). p. 179-208. ISSN 1130-5029

La versión más crítica de la guerra, sin embargo, la ofreció Crucible of Empire: The Spanish American War (1999). El actor Edward James Olmos narra este documental de dos horas de duración producido por Great Project Film Company para PBS en el que la guerra es presentada como un momento de inflexión decisivo en la historia norteamericana. A diferencia de todas las producciones sobre el tema realizadas hasta la fecha, Crucible of Empire es la única que se aleja del carácter partidista (y a veces maniqueo) de este tipo de producciones que tienden a caer en una visión nostálgica de la historia o en una objetividad entendida como la repetición sistemática de la narrativa dominante. Si bien no se recogen las opiniones de historiadores cubanos o españoles, sí interviene a menudo el cubano-americano Louis A. Pérez Jr., una de las mayores autoridades sobre el tema y también una de las voces más críticas del intervencionismo norteamericano. Participan, asimismo, figuras relevantes de la historiografía o la política filipinas, algo impensable, por absurdo que parezca, en otras producciones de este tipo. La tesis principal que se desprende del documental es, asimismo, la que ha terminado por imponerse en la mayoría de los debates sobre la guerra: una vez que la frontera había sido conquistada, se necesitaban nuevos espacios y geografías donde poder dar rienda suelta a las energías acumuladas. ¿Qué mejor salida que un imperio de ultramar? La guerra estableció Norteamérica como una potencia mundial con las colonias de Puerto Rico y Filipinas y el régimen neocolonial que se estableció en Cuba. El documental traza paralelismos entre estas intervenciones y otras más recientes de los Estados Unidos, como las de Vietnam y los Balcanes. Impulsados tanto por el patriotismo como por ambiciones imperiales, los Estados Unidos fueron a la guerra con España consiguiendo la victoria en cuestión de meses. Los rebeldes en Cuba y Filipinas, que habían visto inicialmente a los norteamericanos como salvadores, pronto comprendieron que habían sustituido un dominio imperial por otro. Meses después de la rendición de los españoles, los norteamericanos estaban liderando su propia guerra colonial contra los rebeldes filipinos. La intervención en los asuntos cubanos fue especialmente intensa hasta 1934 y dejó un residuo de antiamericanismo. Crucible of Empire fue, además, el primer (y único documental) que ha examinado el papel y la división en el seno de la comunidad afroamericana ante la guerra. Si bien algunos de sus líderes argumentaban que un pueblo oprimido no debía levantarse en armas en favor de sus opresores, otros mantenían que la participación valiente y decidida de los soldados afroamericanos en el conflicto mejoraría su posición social. El documental no pasa por alto las muestras de racismo y discriminación en el seno de las tropas norteamericanas. Se detiene, por ejemplo, en los acontecimientos que tuvieron lugar en la ciudad de Tampa, Florida, el punto de salida de la invasión de Cuba y que fue el escenario de enfrentamientos raciales, invariablemente ocultados tanto en los documentales como en las publicaciones sobre la guerra. Si bien Crucible of Empire no puede llegar a considerarse una abierta diatriba contra el imperialismo, es el único en examinar desde una perspectiva crítica las contradicciones del proceso mediante el cual Estados Unidos se convirtió en un nuevo poder colonial. 
Nación, mito e historia: la Guerra... - Santiago Juan-Navarro

\subsection{Nostalgias imperiales: la "guerra de cuba" en el cine español}

La cinematografía española no ha producido ninguna obra memorable en relación con este conflicto. El interés de las pocas películas sobre el tema habría que buscarlo más bien en el terreno cultural, sociológico y, sobre todo, político. La mayor parte del cine español de temática militar tendió a centrarse en la Guerra de Marruecos y, luego, en la Guerra Civil. La primera producción sobre lo que en España se vino en denominar como "la guerra de Cuba" fue El héroe de Cascorro (fig. 4), sobre la historia del soldado Eloy Gonzalo. Escrita y dirigida en 1929 por Emilio Bautista (realizador sin apenas experiencia en el cine), se centra en el popular héroe madrileño condecorado durante la guerra por su valentía al defender la posición realista en la villa de Cascorro. En realidad, la gesta de Eloy Gonzalo apenas tuvo relevancia militar. Sin embargo, este personaje se hizo famoso por la necesidad de exaltar un rasgo de heroísmo individual en una guerra que era profundamente impopular entre la clase trabajadora española. En el filme de Bautista las acciones bélicas, sin embargo, ocupan un lugar mínimo en una trama dominada por las relaciones sentimentales de Gonzalo y su novia Isabel. El enemigo (el ejército mambí) es casi invisible y carece de personalidad y motivaciones definidas. Las situaciones melodramáticas acaban por desplazar el componente propagandístico, que queda reducido a unos pocos gestos de exaltación nacionalista.

La valoración estética del filme varía según los críticos. Para Rafael de España, "si esta cinta es modélica en algo es como compendio de todos los defectos del cine mudo español, especialmente en lo que se refiere a la pésima estructura del guión" (2002, p. 503). Joaquín Cánovas Belchí es, sin embargo, más condescendiente: "al margen de su desequilibrio argumental [...], ofrece un interesante ejercicio de realización en el que Emilio Bautista muestra su intuitivo conocimiento de la gramática fílmica, tanto en la composición de los planos como en la utilización de un montaje eminentemente funcional, capaz de otorgar agilidad a todo el relato a partir de secuencias espacial y temporalmente autónomas" (1997, p. 79). Lo cierto es que, si EI héroe de Cascorro sufre serias deficiencias en la construcción de la trama, resuelve con acierto algunos problemas técnicos del cine español de la época. En lugar de abusar de los rótulos explicativos tan abundantes en el período silente, privilegia la función denotativa del propio movimiento de la cámara, las sobreimpresiones y un original uso de los recursos escenográficos.

Dentro ya del cine sonoro, la primera película que trató (aunque tangencialmente) la guerra hispano-norteamericana fue Raza, dirigida por José Luis Sáenz de Heredia (primo de José Antonio Primo de Rivera) en 1942. Su origen se encuentra en el guión que un año antes había escrito el propio Franco y que firmó con el seudónimo Jaime de Andrade (Vázquez Montalbán, 2004, p. 37). El filme, interpretado por Román Gubern como la delirante autosublimación del dictador (1977, p. 10-11), se centra en la Guerra Civil, vista desde la perspectiva caricaturesca del franquismo. Es significativo, sin embargo, que el prólogo arranque con el conflicto hispano- 


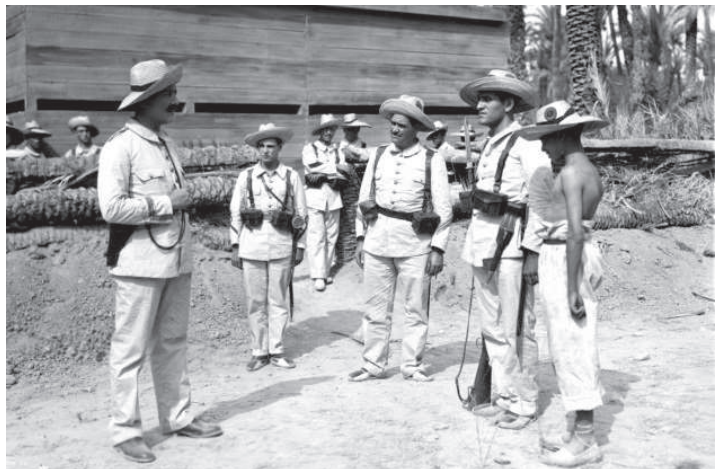

Figura 4: El héroe del Cascorro (1929), de Emilio Bautista. Filmoteca Española. CSJ-N

norteamericano como origen de la contienda y que las dos versiones que se conservan de la película muestren los cambios característicos de la política exterior del franquismo durante el periodo de la autarquía. En la versión original de Raza (la de 1942) el "Desastre" es el resultado de la alianza de las logias masónicas internacionales y los políticos locales. El filme de Sáenz de Heredia (o habría que decir de Franco) se ajusta a un patrón característico del cine de propaganda que habría de buscar en el mundo de la cultura, especialmente en el cine, un vehículo de legitimación política.

En la versión de 1950 (retitulada Espíritu de una raza) se eliminan todas las alusiones a los Estados Unidos y a la masonería como enemigos de España (figs. 5 y 6). En pleno proceso de "normalización" diplomática y ante el nuevo orden resultante de la Segunda Guerra Mundial, era necesario atenuar en lo posible el filofascismo, la xenofobiayelantiamericanismo. Serefuerza, porel contrario,elmensajeanticomunista, muy acorde con los nuevos vientos que corrían con la Guerra Fría y con la nueva orientación que el dictador dio a su política exterior. Como señala Ferrán Alberich, "los historiadores del franquismo han apuntado repetidamente el carácter ecléctico del régimen, que pasó por diversas etapas con la única finalidad de mantenerse en el poder. Raza y Espíritu de una raza son una ilustración de esta actitud" (1997, p. 61).

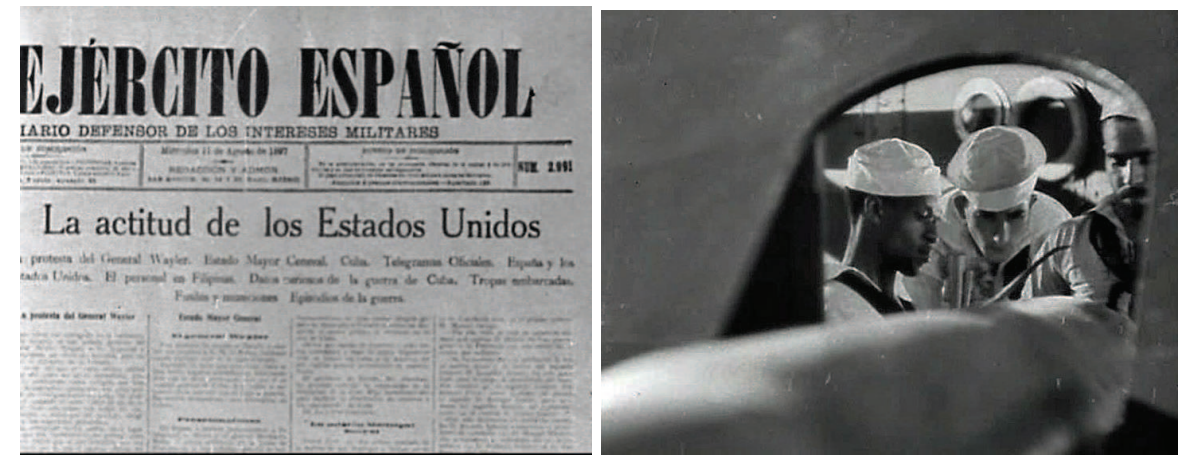

Figura 5 y 6: Fotogramas de Raza (1942) que fueron eliminados en Espíritu de una Raza (1950). Filmoteca Española. CSJ-N 
Si Raza fue la primera película que trataba brevemente la Guerra de Cuba, dicha guerra ofrece el marco dominante de Bambú (fig. 7) dirigida de nuevo por Sáenz de Heredia en 1945. A mitad de camino entre la comedia romántica, el melodrama kitsch y el musical, Bambú es una producción de escasas ambiciones históricas. Concebida para lucimiento exclusivo de la actriz y cantante Imperio Argentina, no consiguió sus objetivos debido a un mal guión y a los problemas internos del rodaje.

Bambú representa la Guerra de Cuba desde una perspectiva absolutamente banal y sin apenas referencias políticas. Se trata, en realidad, de una producción eminentemente comercial con la que Cesáreo González, su productor, quería explotar la popularidad de Imperio Argentina a ambos lados del Atlántico. Esto hacía improcedente la utilización de motivos excesivamente locales o de temas políticamente "sensibles" en Hispanoamérica. El ambiente cubano (reconstruido totalmente en estudio) no tenía otra finalidad que la del color local, pretexto para unos números musicales muy elaborados.

Bambú cuenta la historia de un músico que, tras fracasar sentimental y profesionalmente, se enrola como voluntario en las tropas que marchan a Cuba. Allí se enamora de una vendedora de frutas llamada Bambú. El resultado es un filme extraño y difícilmente clasificable en el que las Guerras de Independencia actúan como telón de fondo de los amores imposibles entre los protagonistas. Bambú establece un patrón que seguirán otras producciones posteriores: un joven soldado español se enamora de una mujer cubana, que aparece representada con los rasgos de una alegoría nacional. Esta tendencia recurrente en el cine español, tanto en el franquismo como en las coproducciones más recientes, no hace sino reflejar un lugar común del discurso colonial. Como señala David Spurr, "the allegorization of colonized nations in terms of the female figure (bodily, rhetorical) has been a cliché of colonial history" (1993, p. 171). El territorio colonizado aparece así representado como el espacio de la seducción. La causa independentista en Bambú queda

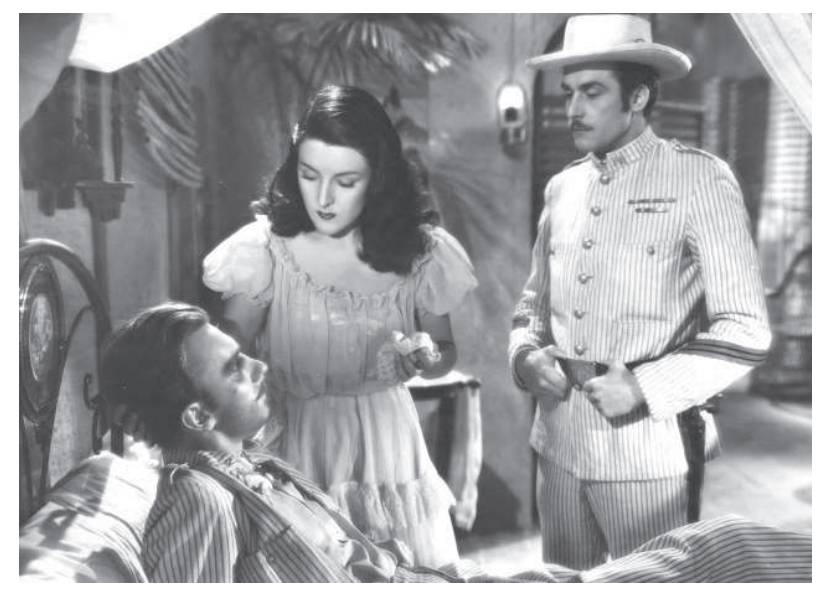

Fig. 7: Bambú (1945), de José Luis Sáenz de Heredia. Filmoteca Española. CSJ-N 
circunscrita al personaje de don Arturo, el dueño de un cabaré local que intenta conseguir los favores sexuales de Bambú extorsionando a su padre. La asociación del independentismo con el ámbito prostibulario y criminal de la colonia es el único elemento político en una producción, por lo demás, intrascendente.

Rodada un año después y estrenada en 1947, Héroes del 95 (fig. 8), de Raúl Alfonso, parece a simple vista un filme de propaganda, pero el mensaje ideológico termina por naufragar en un guión plagado de anacronismos. Aunque sea cinematográficamente patética e historiográficamente irrisoria, Héroes del 95 tiene un particular interés como manifestación de los cambios y contradicciones del franquismo en una delicada coyuntura política. El filme se produce en un momento en el que el régimen de Franco intenta dar muestras de docilidad en el exterior. Esto se aprecia en el tratamiento de las fuerzas beligerantes. Para empezar, los independentistas son presentados con cierto respeto. El villano central de la película es, por supuesto, extranjero, pero no es cubano ni norteamericano, sino un mejicano que se hace llamar "General Tampico" y que dice luchar por la "revolución." Muchos años antes de que estallara dicha Revolución, cuando Méjico vivía todavía bajo el Porfiriato, que simpatizaba más con España que con los EE.UU., aparece aquí este absurdo personaje interpretado por Fernando Sancho, un aragonés que se haría famoso haciendo de bandido mejicano en algunas de las peores películas del cine español. La anécdota podría pasar por una bufonada más del cine histórico de la época, si no fuera porque tiene su explicación política. En un marco internacional que el franquismo siempre vio en términos conspiratorios, el filme se desquita aquí con Méjico, país que acogió al mayor número de exiliados republicanos y que nunca reconoció el régimen de Franco (España, 2002, p. 509).

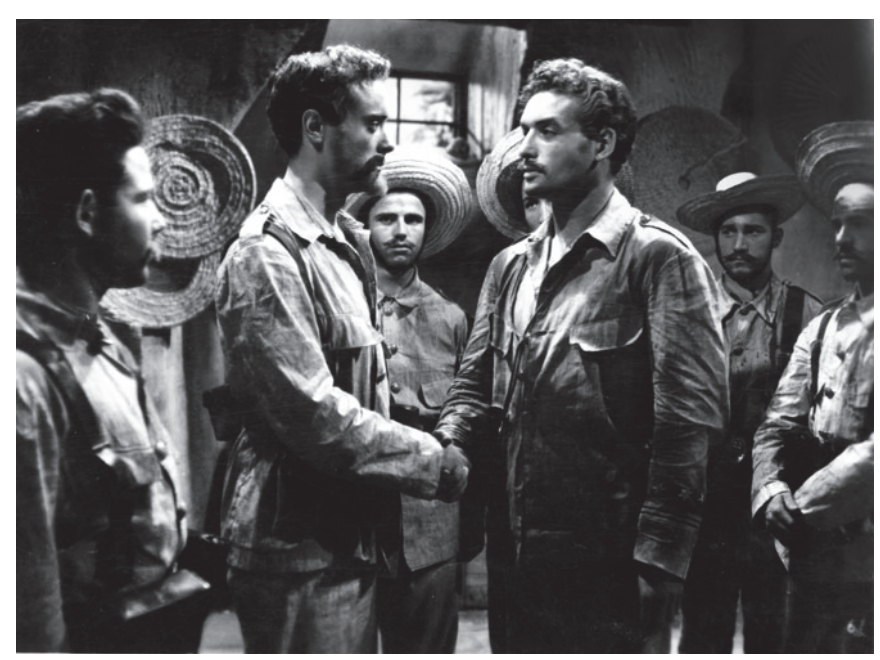

Figura 8: Héroes del 95 (1947), de Raúl Alfonso. Filmoteca Española. CSJ-N 
Nación, mito e historia: la Guerra... - Santiago Juan-Navarro

2.3. Arqueología de una revolución incompleta: las guerras de independencia en el cine cubano

A pesar de la abrumadora cantidad de documentales y largometrajes de ficción que tienen como trasfondo las guerras de independencia, la intervención norteamericana de 1898 no ha sido apenas tratada en el cine cubano. La inmensa mayoría de los títulos de su extensa filmografía se concentran en la guerra contra España iniciada en 1895. Esta es sistemáticamente representada como el elemento inaugural de una teleología nacionalista en la que el actual gobierno revolucionario es visto como culminación de un telos inscrito dentro de una visión providencialista de la historia. El carácter humillante para los cubanos de la intervención norteamericana, que dejó a los mambises al margen del Tratado de París, hace que el 98 sea un tema poco atractivo dentro de la épica característica de su cine histórico. Sin embargo, la presencia ominosa de la intervención norteamericana planea en muchos de sus títulos como la primera dentro de un largo ciclo de agresiones imperialistas y actos de resistencia que se prolongaría hasta nuestros días.

Pero si la visión histórica del fenómeno que proyecta el cine cubano comparte el providencialismo, la simplificación y manipulación de los hechos históricos, la mistificación de sus héroes nacionales y el carácter eminentemente propagandístico del cine bélico norteamericano, el marco de la industria cinematográfica en el que se encuadra la práctica totalidad del cine histórico cubano es realmente único. Recordemos que, a diferencia de otras cinematografías, el cine cubano se consolida como industria en el contexto de un movimiento revolucionario que ha buscado en el pasado su principal fuente de legitimación. Desde su creación por decreto ley el 2 de marzo de 1959, el Instituto Cubano de Arte e Industria Cinematográficos (el ICAIC) ha sido uno de los más eficaces instrumentos de propaganda de la revolución y ha explorado la genealogía moral del nuevo orden como base de la identidad nacional. Si la estética de sus películas ha variado a lo largo del tiempo, dependiendo de los cambios institucionales y de la idiosincrasia de cada realizador, en lo político han respondido, por lo general, a un rígido esquematismo. La tendencia al panfleto, que se advierte ya en los años 60, fue especialmente acusada durante las dos décadas siguientes bajo el influjo de la antigua Unión Soviética. A finales de los 80 se empezaron a ensayar tímidos intentos de apertura, que no llegaron a materializarse hasta una década después, tras la caída del Muro de Berlín y la apertura de un debate (siempre ambiguo y limitado) en la isla.

El cine histórico producido durante las últimas décadas en Cuba ha venido reflejando estos cambios. A la febril experimentación formal de los primeros años, sucedió un largo periodo de encorsetamiento estético e ideológico. El vanguardismo cedió terreno al social-realismo, la frescura y originalidad de las primeras obras, fue cayendo pronto en la rutina de la producción en serie. Las guerras de independencia 
Revista de Humanidades, 37 (2019). p. 179-208. ISSN 1130-5029

tuvieron una gran importancia en la creación del imaginario histórico de la revolución y en la configuración de lo que Rafael Rojas ha llamado la "hermenéutica oficial de la historia de Cuba" (Rojas, 1998, p. 88). Como suele ocurrir en el cine histórico, las producciones del ICAIC nos hablan más del periodo en que fueron realizadas (su presente de producción) que del periodo al que se refieren (el pasado que dicen recrear). Comentaré a continuación filmes representativos de cada una de estas etapas.

En primer lugar, tenemos el grupo de películas creadas a la sombra de la campaña de los "100 años de lucha". La producción del cine histórico cubano durante la década de los 60 estuvo marcada por este aniversario. Coincidiendo con el centenario del levantamiento de Carlos Manuel de Céspedes en 1868, se sucedieron durante cuatro años (de 1968 a 1971) los actos de homenaje y los discursos oficiales dedicados a los héroes de la independencia. Diarios y revistas dedicaron suplementos y números monográficos al tema. Los historiadores se volcaron en monografías que releían la Cuba del siglo XIX como origen de la Revolución del XX. Pero fue el discurso pronunciado por Fidel Castro el 10 de octubre de 1968 en la Demajagua, el que estableció las claves para entender un nuevo concepto de la historia nacional: “¿Qué significa para nuestro pueblo el 10 de octubre de 1868? ¿Qué significa para los revolucionarios de nuestro país esta gloriosa fecha? Significa sencillamente el comienzo de cien años de lucha, el comienzo de la revolución en Cuba, porque en Cuba solo ha habido una revolución: la que comenzó Carlos Manuel de Céspedes el 10 de octubre de 1868 y que nuestro pueblo lleva adelante en estos instantes" (Castro Ruz, 1975, p. 61). En apenas un párrafo, Fidel Castro homogeneiza varios momentos históricos diferentes, se arroga el papel de intérprete absoluto del destino de la nación y se declara continuador de las guerras de independencia. La revolución no comenzó pues con el asalto al Cuartel Moncada el 26 de julio de 1953, o con el desembarco del Granma el 2 de diciembre de 1956, o con la entrada en La Habana del Ejército Rebelde el 1 de enero de 1959, sino con la insurrección de Céspedes el 10 de octubre de 1868. De acuerdo con esta visión teleológica de la historia, las guerras de independencia contra España fueron así parte de un proceso en el que se enmarcan todos los acontecimientos políticos de la Cuba moderna y que tiene su particular "fin de los tiempos" en la revolución castrista.

En esta gestación de la narrativa y el imaginario revolucionarios tuvo gran importancia la labor llevada a cabo por los cineastas del ICAIC. En su revista Cine cubano, se sucedieron los manifiestos, reseñas y artículos de opinión donde se volvía una y otra vez sobre los orígenes de la nación cubana en su lucha revolucionaria y la necesidad de plasmar cinematográficamente dicha experiencia. Paradigmático fue el número especial dedicado a este tema (en 1971), que se abre con un texto de José Martí sobre la primera de las guerras de independencia y el mencionado discurso de Fidel. Esta superposición entre los movimientos independentistas de finales del XIX y la Revolución del XX, así como la equiparación recurrente de 
dos de sus líderes (Martí y Fidel), es algo que va a marcar la producción del cine histórico cubano desde finales de los 60 hasta muy recientemente. ${ }^{6}$

Filmes como Lucía (de Humberto Solás), La odisea del General José (de Jorge Fraga), Hombres de mal tiempo (de Alejandro Saderman) y Páginas del Diario de José Martí (de José Massip), reflejan el espíritu cultural de una época en la que los cineastas del ICAIC aspiraban a una síntesis entre experimentación formal y propaganda política (Paranaguá 2003, p. 45). Al vanguardismo y estilización de estas obras se suma un claro mensaje político destinado a conectar la Revolución con el pasado nacional y, muy especialmente, con la tradición independentista. El origen de la primera de las guerras de independencia, la insurrección de 1868, constituye el motivo central del filme más representativo de este ciclo: La primera carga al machete (fig. 9), dirigida por Manuel Octavio Gómez en 1969. Ambientada en los orígenes de la Guerra de los Diez Años (1868-1878), cuenta la legendaria toma y defensa de Bayamo por los insurgentes. Para reconquistar la ciudad, el gobernador español envía una columna de 700 hombres. Éstos son derrotados por los cubanos que, a las órdenes del General Máximo Gómez, caen sobre ellos con sus machetes. El filme utiliza técnicas del documental y del cine-encuesta, con entrevistas a los integrantes de ambos bandos, sonido directo y tomas de las batallas filmadas cámara en mano. Las canciones de Pablo Milanés comentan, a la manera del teatro de Brecht, los sucesos narrados. La primera carga habla de un acontecimiento histórico que tuvo lugar en 1868, pero simultáneamente reflexiona sobre la situación del país cien años después. La Guerra de los Diez Años (1868-1878), La Guerra Chiquita (1879-1880), La Guerra de Independencia (1895-1898), las luchas contra Machado (1924-1933) y contra Batista (1940-1944; 1952-1959), la Revolución de 1959 y la permanente lucha contra las injerencias del gobierno norteamericano, son vistas como etapas dentro de una larga guerra de liberación nacional. En este mismo sentido, el filme de Gómez se encarga de recordarnos continuamente la actualidad de lo acontecido cien años atrás y utiliza para ello toda una serie de técnicas dramáticas de filiación brechtiana que nos mueven a interpretar el pasado en función del presente (Juan-Navarro, 2006, p. 108). La acción militar ocurrida el 4 de noviembre de 1868, la primera carga al machete a la que alude el título del filme, se revela, así como metáfora central y auténtico mito del origen de la Revolución Cubana. La batalla a la que alude el título no fue el primer acto independentista, pero sí podría considerarse como el primero de una larga tradición guerrillera, adquiriendo de esta forma el valor de hecho histórico fundacional en el imaginario revolucionario.

6 Para una evaluación del éxito de la campaña de los 100 Años de Lucha, véase Miller (2003, pp. 147-162). La importancia de la contribución del ICACI ha sido señalada por Fornet (1990, p. 87) y Martins Villaça (2006, pp. 12, 172, 188). 


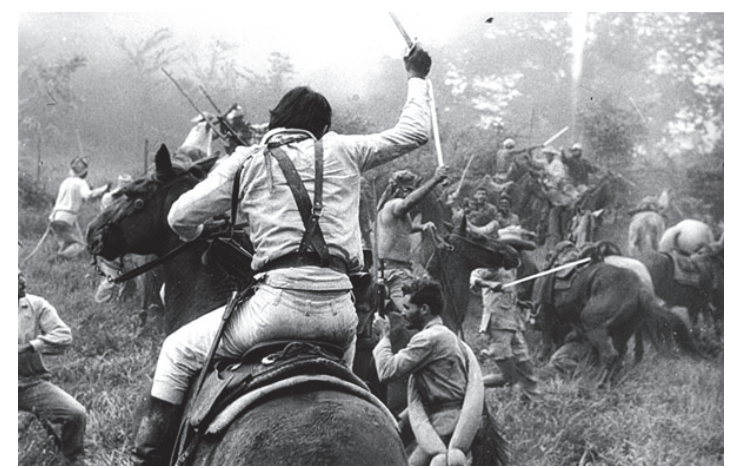

Figura 9: La primera carga al machete (1969), de Manuel Octavio Gómez. Cinemateca de Cuba. CSJ-N

Esta misma aspiración revolucionaria, tanto en lo político como en lo estético, es el punto de partida de una de las obras más interesantes y olvidadas sobre las Guerras de Independencia. Páginas del diario de José Martí (1971) es un filme tan inclasificable como controvertido. A mitad de camino entre el documental y el cine de ficción, la película de José Massip es un atrevido ejercicio de hibridez cinematográfica, en el que se superponen los tiempos, las voces, los materiales gráficos, los géneros y los medios audiovisuales. Si en lo formal el filme es de una complejidad tal que nos remite al neobarroco más delirante, en lo ideológico se caracteriza por el didactismo propio del cine de propaganda. Y es que, en gran medida, Páginas es la traslación cinematográfica del mencionado discurso de Fidel, algunos de cuyos fragmentos más significativos (como el pasaje citado) reaparecen en el filme. Curiosamente no hay ni rastro del Comandante en los créditos, como dando a entender que todos los diálogos de la película provienen de la obra martiana.

Estructuralmente Páginas consta principalmente de dos modos discursivos: 1) un componente documental organizado en torno a citas célebres de Martí y Fidel, que son leídas por diferentes voces superpuestas a imágenes documentales (tanto del siglo XIX como de XX); y 2) un elemento narrativo en el que se entretejen varios relatos procedentes del "Diario de Campaña de José Martí". El elemento documental (entremezclado con una increíble variedad de formas expresivas) domina los primeros 11 minutos. A partir de ese momento se sigue cronológicamente el diario, que narra desde el desembarco de Martí en Cuba hasta su muerte en Dos Ríos, el 19 de mayo de 1895. El filme se cierra en la Cuba revolucionaria con el testimonio del nieto de uno de los soldados que acabó con la vida de Martí y que es miembro de una brigada de jóvenes artistas de vanguardia.

Solo se conservan dos reseñas de la película: una muy elogiosa de Enrique Pineda Barnet y otra de Alejo Carpentier que tampoco puede ser más entusiasta. Sin embargo, es sabido que Páginas del diario de José Martí tuvo una pésima acogida "oficial", hasta el punto de ser primero mutilada y después "archivada". Cabría preguntarse pues: ¿por qué si el filme de Massip era tan "políticamente 
correcto" y recibió los elogios más entusiastas de un intelectual tan destacado (y afín al régimen) como Carpentier fue relegado al olvido? ¿Por qué el documental que años después realizó Tomas Piard sobre él, con el significativo título de "En busca del filme perdido" (y que se hacía la pregunta anterior) nunca llegó a emitirse por la televisión cubana, productora del documental? Una respuesta podría estar en el contexto histórico de su producción: el comienzo de lo que algunos llamaron el "quinquenio gris (que abarcaría de 1971 a 1976), otros "decenio gris" (la década de los 70) y otros simplemente el proceso de "sovietización" del régimen (desde 1971 hasta 1985). La "Declaración del Primer Congreso de Educación y Cultura" (1971) abominaba de los vanguardismos formales y apostaba por un realismo popular y didáctico, "contrario a las tendencias de élite" (DECLARACIÓN DEL PRIMER CONGRESO NACIONAL DE EDUCACIÓN Y CULTURA, 1971, p. 18). Filmes como el de Massip fueron considerados como elitistas por su experimentalismo, y de dudoso gusto, por permitirse libertades en el tratamiento de una figura tan "sagrada" como la de Martí.?

Es precisamente en pleno Quinquenio Gris cuando se produce un incremento en el cine histórico ICAIC, pero con una estética muy diferente de la empleada por el Instituto durante sus comienzos. Un ejemplo de este giro radical experimentado por la cinematografía cubana es la filmografía del más famoso de sus documentalistas: Santiago Álvarez. Cortometrajes documentales como El primer delegado (1975) y Mi hermano Fidel (1977), de Santiago Álvarez, son representativos de un cine crecientemente didáctico y patológicamente propagandístico, que reescribe el siglo XIX (las Guerras de Independencia contra España) desde la óptica política del XX (la revolución castrista). De acuerdo con esta visión teleológica y figurativa del devenir, la historia de Cuba consiste en una progresión de movimientos revolucionarios que encuentra en el actual gobierno la culminación de ese "telos". De estos documentales históricos de Álvarez se desprende una idea recurrente en el imaginario político de la revolución: la figura de José Martí anuncia y prefigura la de Fidel, quien a su vez encarna la de Martí (figs. 10, 11, 12 y 13). ${ }^{8}$ No deja de ser paradójico que el cine del ICAIC aspirara a ser materialista y dialéctico, cuando su fábrica misma ha respondido casi siempre a una concepción cuasi-religiosa, mesiánica y antidialéctica de la historia; una visión en la que lo histórico termina por ceder paso a lo trascendente y el tiempo parece detenido; una visión, en suma, que responde al ámbito del mito y la escatología, más que al de la historia propiamente dicha.

7 De hecho, Páginas fue una película que se "archivó" tras haber sido censurada inmediatamente después de su estreno, pero no por razones políticas, sino estéticas. Para una relación de la extraña historia de esta producción y sus problemas con la censura, véase Juan-Navarro (2013, pp. 19-36).

8 Para un análisis detallado de estos dos cortometrajes de Santiago Álvarez en relación con la “mitologización” de la historia en el cine del ICAIC, véase Juan-Navarro (2012, pp. 119-138). 

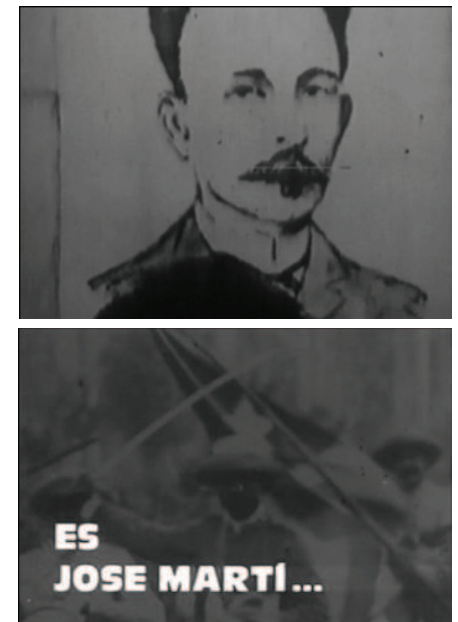

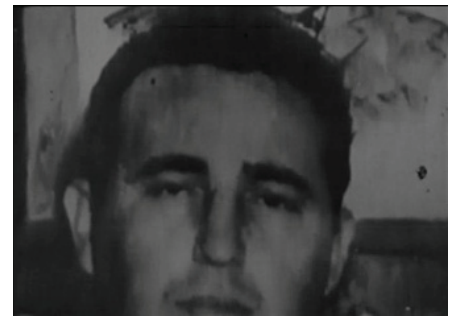

..PORQUE EL UNICO

AUTOR INTELEGTUAL

DEL ASALTO

AL MONCADA

ES

JOSE MARTI...

Figura. 10, 11, 12 y 13: El primer delegado (1975), de Santiago Álvarez. La identificación entre las figuras de Martí y Fidel se repite interminablemente no sólo a través de la voz en off, sino también mediante la superposición de sus imágenes y el abuso de rótulos engañosos. Cinemateca de Cuba. CSJ-N

También es en esta misma época cuando Rigoberto López realiza el único filme dedicado plenamente a la guerra del 98 y que significativamente lleva por título $L a$ primera intervención (1974). El documental de López ofrece una buena síntesis de la metanarrativa castrista en torno al 98 . El propio título hace referencia al comienzo de una larga serie de injerencias de los gobiernos norteamericanos en la política cubana. Esta primera intervención, justificada ante la opinión pública mediante el engaño, no fue sino el comienzo de una visión imperial en el país vecino que se prolongaría hasta nuestros días. A la metódica relación de los diferentes pasos de la campaña se superponen constantes referencias a la guerra de Vietnam y a otras manifestaciones del imperialismo norteamericano. La secuencia final subraya esta "presentización de la historia" que caracteriza al cine histórico cubano y que gusta de volver una y otra vez a las luchas independentistas del siglo XIX como génesis de una nación cuya identidad aparece indisolublemente unida a la Revolución y a su Líder Máximo. Como tantos otros filmes documentales el clímax del documental muestra la entrada de Fidel con las tropas revolucionarias en La Habana el 1 de enero de 1959. Sobre estas imágenes se superponen bajo la forma de los intertítulos característicos de los documentales didácticos del ICAIC unas palabras que, aunque no se identifican explícitamente, nos remiten a un texto que José Martí publicó en Patria el 19 de agosto de 1893: "Del norte hay que ir saliendo" "Al sol, y no a la nube" "Al remedio único, constante" "y no a los remedios pasajeros” "¡A LA PATRIA LIBRE!”. Entre cada intertítulo reaparecen imágenes de: 1) la entrada de Fidel en La Habana; 2) imágenes de combates en las guerras de independencia (procedentes de otros filmes del ICAIC); y 3) el derribo del águila imperial que coronaba el monumento a las víctimas del Maine sobre el malecón de La Habana. 
La década del 70 se caracterizó también por la proliferación de coproducciones con otros países latinoamericanos. A la exploración de la historia nacional en la campaña de los "100 años de lucha", que se dio por concluida en 1971, se fue sumando un internacionalismo, que tenía su correlato político y militar en la progresiva implicación de Cuba en conflictos internacionales, como Angola, Sudáfrica y Etiopía. Fue el comienzo de las coproducciones del Instituto con otros países latinoamericanos y el momento culminante de la influencia de la revolución cubana en el continente. Fue también el periodo de auge de las epopeyas históricas en las que se exaltaban algunos de los héroes de la independencia como precursores del socialismo. Dos de los títulos más destacados de esta tendencia fueron, Mina, viento de libertad (coproducción cubano-mexicana dirigida por el realizador vasco Antonio Eceiza en 1976) y Tupac Amaru (coproducida con Perú en 1984 y dirigida por Federico García). En ambos casos se trata de un cine doctrinario y didascálico de escasas ambiciones estéticas. Los diálogos son grandilocuentes, la actuación tiende a la rigidez del panfleto y el exceso de información histórica acaba por ahogar la trama. Tanto en Mina como en Tupac Amaru el pueblo queda reducido al mero papel de comparsa del héroe mesiánico convertido en puro gesto y lema.

Por lo que se refiere a las coproducciones "oficiales" con España, habrá que esperar hasta finales del siglo XX para que el cine español vuelva a mostrar interés en la Guerra de Cuba. En el año del Centenario (1998), los hermanos Teodoro y Santiago Ríos dirigieron Mambí (fig. 14), una coproducción entre España y el ICAIC con guión del cubano Ambrosio Fornet. Mambí cuenta la historia de Goyo, un joven jornalero canario al que obligan a alistarse en el ejército para luchar contra los mambises. A través de los protagonistas de uno y otro bando, Mambi muestra los intereses irreconciliables de las naciones beligerantes: España, en el ocaso de su imperio, Cuba, en vísperas de su independencia, y Estados Unidos, el país que,
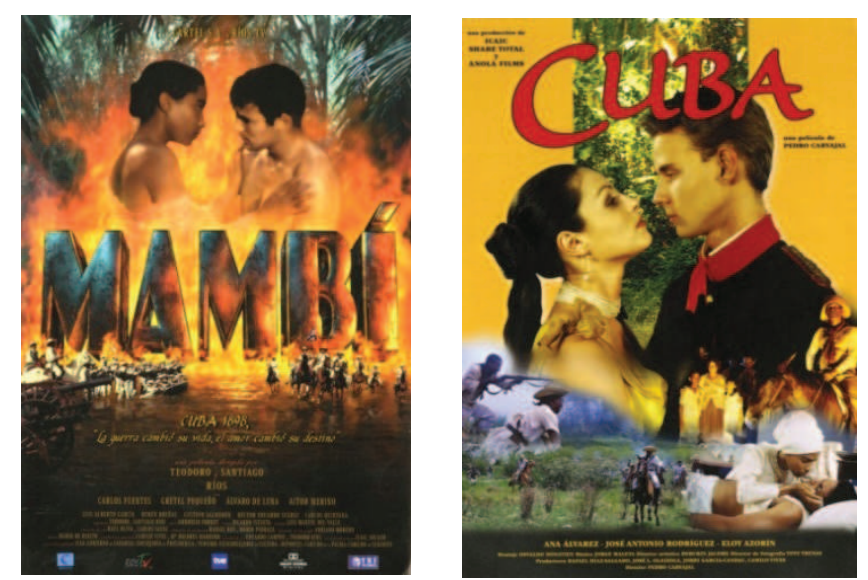

Figs. 14 y 15: Carteles anunciadores de las co-producciones hispano-cubanas Mambí (1998) y Cuba (2002). Filmoteca Española. CSJ-N 
Revista de Humanidades, 37 (2019). p. 179-208. ISSN 1130-5029

aunque ajeno inicialmente al conflicto, acabaría por sacarle el mayor beneficio. Cuatro años después (2002), se estrena una película similar: Cuba (fig. 15), del director español Pedro Carvajal. Coproducida también con el ICAIC, presenta los amores de Dolores Velasco, simpatizante de la independencia cubana, y Santiago, un oficial español enviado a reforzar la defensa contra los independentistas. Como en Mambí, la acción en Cuba tiene lugar tras el asesinato de Maceo en 1896 y se extiende hasta el fin de la presencia española en la isla. Al igual que en la película de los hermanos Ríos, la de Carvajal se vale de una trama amorosa para presentar una historia de aventuras en medio de un conflicto bélico. De la misma manera que en el filme anterior, en Cuba los villanos últimos no son los españoles, sino el nuevo ejército de ocupación.

\section{GONGLUSIONES}

La que en España se conoció como "La Guerra de Cuba", en EE.UU. como "The Spanish-American War", pero que en propiedad habría que llamar "guerra cubano-hispano-norteamericana", alcanza dimensiones que van más allá de simples transformaciones geopolíticas. Se trata de un conflicto dotado de una gran fuerza simbólica por cuanto supuso además un parteaguas en los debates internos sobre la identidad nacional en cada uno de los países que participaron en el conflicto. Si bien en el caso norteamericano podría considerarse como la consecuencia lógica de la doctrina del "Destino Manifiesto", que a mediados del siglo XIX había llevado ya a la guerra con México (1846-1848) --con la consiguiente anexión a la Unión de gran parte de los territorios del Suroeste, el 98 marca una dimensión global (transcontinental) e imperial de dimensiones nunca vistas hasta entonces. La interpretación estadounidense estuvo (y sigue estando) marcada por la ambigüedad y una clara división de opiniones entre quienes consideran el 98 como una guerra accidental o inevitable; innecesaria o imprescindible; una guerra que para algunos fue inducida por la opinión pública, para otros fue instigada por la clase política y/o los centros financieros, y para un tercer grupo fue el resultado de la dinámica consustancial de una nación que concebía la incesante expansión de su territorio como parte de su propia idiosincrasia. El cine ha recogido estas interpretaciones, subrayando los aspectos más espectaculares y menos polémicos del mito. Así es significativa, la omnipresencia de los Rough Riders de Roosevelt y la ausencia, en cambio, del conflicto en Filipinas. La explicación de esta "amnesia imperial", como recientemente calificó este fenómeno Matthew Frye Jacobson (1999, p. 116), es bien simple: a diferencia del caso cubano, el conflicto en Filipinas no tuvo coartada moral alguna. Salvo en sus primeros momentos, no fue una guerra contra un imperio europeo, sino el resultado de la traición a los independentistas filipinos que habían luchado contra España y luego tuvieron luego que enfrentar a sus nuevos "propietarios" (el Tratado de París obligó al gobierno español a vender Filipinas y 
otros territorios a EE.UU. por veinte millones de dólares). Fue además una guerra que duró demasiado (tres años) y costó también demasiado (se calcula que murieron 220.000 filipinos y 4.200 estadounidenses). A diferencia de la corta campaña de Cuba, la de Filipinas difícilmente pudo merecer los calificativos de "little" o "splendid", de ahí la ocultación de la guerra no solo en su momento, sino también durante el centenario e incluso hoy día; una guerra olvidada a pesar de ser uno de los precedentes más claros de los conflictos en los que EE.UU. se vería implicado a lo largo de todo el siglo XX y que guarda una perturbadora semejanza incluso con otros más recientes, como los de Vietnam, Iraq y Afganistán (Grandin, 2006, pp. 1-9).

En el cine cubano la atención se ha centrado en el poder legitimador que las Guerras de Independencia del siglo XIX han tenido en la construcción de una engañosa identidad en la que se superponen arbitrariamente los conceptos de nación, pueblo, Estado, Revolución y Líder Máximo. En Isla sin fin, Rafael Rojas desarrolla en profundidad una idea apuntada también por otros críticos del nacionalismo cubano: la noción de que en los últimos dos siglos la cultura cubana se ha saturado de un imaginario redentor, violento y justiciero, que ha terminado por desplazar las representaciones liberales, cívicas y democráticas de la nación (Rojas, 1998, pp. 73-104). El metarrelato dominante de la identidad nacional quedó reducido, ya en la primera década del castrismo, al mito de la Revolución como comienzo y fin de la historia cubana, una historia que tendría su origen en las Guerras de Independencia iniciadas en 1868 y que culminaría en la institucionalización del castrismo durante la década de 1970. Este metarrelato habría de adoptar toda la parafernalia mitológica de cualquier doctrina religiosa con: su visión totalizante y su momento de revelación; su añorada génesis y prometido apocalipsis; su visión profética preservada en textos canónicos; su genio fundador y la promesa del regreso de un Mesías redentor; su dogma y sus herejías; así como todo un arsenal de imágenes emblemáticas, banderas, metáforas, aniversarios, efemérides y escenarios dramáticos. Todos estos rasgos revelan lo que George Steiner, en Nostalgia for the Absolute, define como la insatisfacción de una cultura que, aunque secular, gravita hacia las formas religiosas del mundo político (1997, p. 2). La combinación de un nacionalismo mesiánico con un marxismo providencialista fue determinante en la configuración del metadiscurso de la revolución, que el ICAIC llevó al cine de forma mecánica y, a menudo, caricaturesca.

Para los historiadores españoles hay un consenso generalizado en que la guerra marcó no solo el fin de un imperio, sino también el comienzo de un debate aún no resuelto sobre la identidad de España y su papel en el nuevo orden internacional. Como indica su propio nombre, la Generación del 98 estuvo fuertemente marcada por el "Desastre", así como por la necesidad de una regeneración moral en la vida política e intelectual del país. Esta reflexión en el ámbito cinematográfico es de una superficialidad alarmante. La visión del 98 no es hoy día, desde luego, tan maniquea como lo fue durante la dictadura franquista, pero la autocrítica no va mucho más allá de algunas poses políticamente correctas. Las últimas películas coproducidas con Cuba a la sombra del centenario proyectan la mala conciencia de la antigua metrópoli 
Revista de Humanidades, 37 (2019). p. 179-208. ISSN 1130-5029

a través de relatos de iniciación en los que un joven español sufre un despertar de su conciencia que le lleva a integrarse en la lucha emancipadora (Mambi) o a admirar la nobleza de la causa independentista $(\mathrm{Cuba})$. La integración del peninsular dentro del marco cubano se dramatiza mediante el ritual de posesión de una mujer que encarna la nación colonizada. El villano en ambos casos no es tanto el imperio español, que da sus últimos coletazos, como el imperialismo norteamericano, en pleno apogeo.

Si bien las narrativas cinematográficas sobre este acontecimiento pueden ser muy dispares, todas coinciden en presentar el conflicto como un mito del origen de los diferentes proyectos de construcción nacional y de su configuración discursiva. Lo interesante es que se trata de un fenómeno cuyas repercusiones llegan hasta nuestros días, tal y como prueban: la incesante implicación de EE.UU. en aventuras imperiales (o neocoloniales) a partir de aquel momento; los continuos problemas en la definición de la identidad de una España que muchos siguen considerando "invertebrada"; y la perpetuación de un bloqueo sobre Cuba, que no es sino el resultado de una "lógica" similar a la que llevó a la intervención del ejército norteamericano en 1898.

\section{BIBLIOGRAFÍA}

Alberich, Ferrán (1997). Raza. Cine y Propaganda en la inmediata posguerra. Archivos de la Filmoteca, n $^{\circ} 27$, pp. 50-61.

Allen, Robert C. (1977). Vaudeville and Film 1895-1915: A Study in Media Interaction. Tesis doctoral. The University of Iowa.

Bitzer, G.W. (1973). Billy Bitzer: His Story. The Autobiography of D.W. Griffith's Master Cameraman. New York: Farrar, Straus and Giroux.

Bottomore, Stephen (2007). La guerra hispano-norteamericana en las pantallas del mundo. Secuencias, $\mathrm{n}^{\circ}$ 26, pp. 33-52.

Cánovas Belchí, Joaquín (1997). El héroe de Cascorro. En Pérez Perucha, Julio (coord.). Antología crítica del cine español, 1906-1995. Madrid: Cátedra, pp, 77-79.

Castro Ruz, Fidel (1976). En la velada conmemorativa de los Cien Años de Lucha. Discursos. La Habana: Instituto Cubano del Libro, vol. 1, pp. 60-61.

España, Rafael de (2002). Las sombras del encuentro. España y América: Cuatro siglos de historia a través del Cine. Badajoz: Departamento de Publicaciones de la Diputación de Badajoz.

Declaración del Primer Congreso Nacional de Educación y Cultura (1971). Casa de las Américas, $\mathrm{n}^{\circ}$ 65-66, pp. 4-19.

Fornet, Ambrosio (1990). Trente ans de cinema dans la Révolution. En Paranaguá, Paulo Antonio (coord.). Le cinéma cubain. Paris: Centre Georges Pompidou, pp. 79-106.

Gagliasso, Dan (2000). Rough Riders, Moviemakers, and History: Hollywood Images of Theodore Roosevelt and the First U.S. Volunteer Cavalry. The Journal of Arizona History, vol. 41, n 3, pp. 307-330 
Nación, mito e historia: la Guerra... - Santiago Juan-Navarro

Gomery, Douglas (1992). Shared Pleasures: A History of Movie Presentation in the United States. Madison: University of Wisconsin Press.

Grandin, Greg (2006). Empire's Workshop: Latin America, the United States, and the Rise of the New Imperialism. New York: Metropolitan Books.

Gubern, Román (1977). Raza (Un ensueño del general Franco). Madrid: Ediciones 99.

Gunning, Tom (1986). The Cinema of Atraction(s): Early Film, Its Spectators and The Avant-Garde. Wide Angle, vol. 8, n 3, pp. 58-70.

Jacobson, Matthew Frye (1999). Imperial Amnesia: Teddy Roosevelt, the Philippines, and the Modern Art of Forgetting. Radical History Review, $\mathrm{n}^{\circ}$ 73, pp. 116-127.

Juan-Navarro, Santiago (2006). La primera carga al machete, de Manuel Octavio Gómez: Cine, mito y revolución. En Amiot, Julie, y Berthier, Nancy (coord.). Cinéma et Révolution cubaine. Lyon: Université Lyon 2 - GRIMH, pp. 105-113.

Juan-Navarro, Santiago (2012). Historia, mito y propaganda: Fidel Castro en el cine de Santiago Álvarez. Revista Hispano Cubana, no 43, pp. 119-138.

Juan-Navarro, Santiago (2013). De Los primeros treinta a Páginas del diario de José Martí: la mitologización de la historia en el cine de José Massip. Frame, no 9, pp. 19-36.

Kaplan, Amy (1999). The Birth of an Empire. PMLA, no 114, pp. 1069-1079.

Kessler, Frank, y Lenk, Sabine (2018). What is a fake image? En Curtis, Scott, et al (coords.). The Image in Early Cinema. Form and Material. Bloomington: Indiana University Press, pp. 228-236.

Mahan, Alfred Thayer (1898). The Influence of Sea Power upon History, 1660-1783. Boston: Little, Brown, \& Co.

Martins Villaça, Mariana (2006). OInstituto Cubano del Arte e Industria Cinematográficos (ICAIC) e a política cultural em Cuba. Tesis Doctoral. Universidade de São Paulo.

Musser, Charles (1990). The Emergence of American Cinema: The American Screen to 1907. New York: Charles Scribner's Sons.

Paranaguá, Paulo Antonio (2003). Cine documental en América Latina. Madrid: Cátedra.

Pizarroso Quintero, Alejandro (1998). Guerra, Cine e Historia. La guerra de 1898 en el cine. Historia y Comunicación Social, $\mathrm{n}^{\mathrm{o}}$ 3, pp. 143-162.

Rabinovitz, Lauren (1998). For the Love of Pleasure: Women, Movies, and Culture in Turn-of-the-Century Chicago. New Brunswick: Rutgers University Press.

Riesman, David (2001). The Lonely Crowd: A Study of the Changing American Character. New Haven: Yale University Press.

Rojas, Rafael (1998). Isla sin fin: Contribución a la crítica del nacionalismo cubano, Miami, Ediciones Universal.

Shohat, Ella, y Stam, Robert (1994). Unthinking Eurocentrism: Multiculturalism and the Media. Londres y Nueva York, Routledge. 
Revista de Humanidades, 37 (2019).p. 179-208. ISSN 1130-5029

Sklar, Robert (1975). Movie-Made America: A Cultural History of American Movies. New York: Random House.

Spurr, David (1993). The Rhetoric of Empire: Colonial Discourse in Journalism, Travel Writing, and Imperial Administration. Durkham: Duke University Press.

Steiner, George (1997). Nostalgia for the Absolute. Toronto: Anansi.

Turner, Frederick Jackson (1921). The Frontier in American History. New York: Henry Holt \& Co.

Vázquez Montalbán, Manuel (2004). Los demonios familiares de Franco. Barcelona: Mondadori. 
